\title{
Control of breathing by interacting pontine and pulmonary feedback loops
}

\author{
Yaroslav I Molkov*, Bartholomew J Bacak², Thomas E Dick², llya A Rybak ${ }^{2}$ \\ From Twenty Second Annual Computational Neuroscience Meeting: CNS*2013 \\ Paris, France. 13-18 July 2013
}

The medullary respiratory network generates respiratory rhythm via sequential phase switching, which in turn is controlled by multiple feedbacks including those from the pons and nucleus tractus solitarii; the latter mediates pulmonary afferent feedback to the medullary circuits. It is hypothesized that both pontine and pulmonary feedback pathways operate via activation of medullary respiratory neurons that are critically involved in phase switching. Moreover, the pontine and pulmonary control loops interact, so that pulmonary afferents control the gain of pontine influence of the respiratory pattern.
We used an established computational model of the respiratory network [1] and extended it by incorporating pontine circuits and pulmonary feedback (Figure 1). In the extended model, the pontine neurons receive phasic excitatory activation from, and provide feedback to, medullary respiratory neurons responsible for the onset and termination of inspiration. The model was used to study the effects of: (1) "vagotomy" (removal of pulmonary feedback), (2) suppression of pontine activity attenuating pontine feedback, and (3) these perturbations applied together on the respiratory

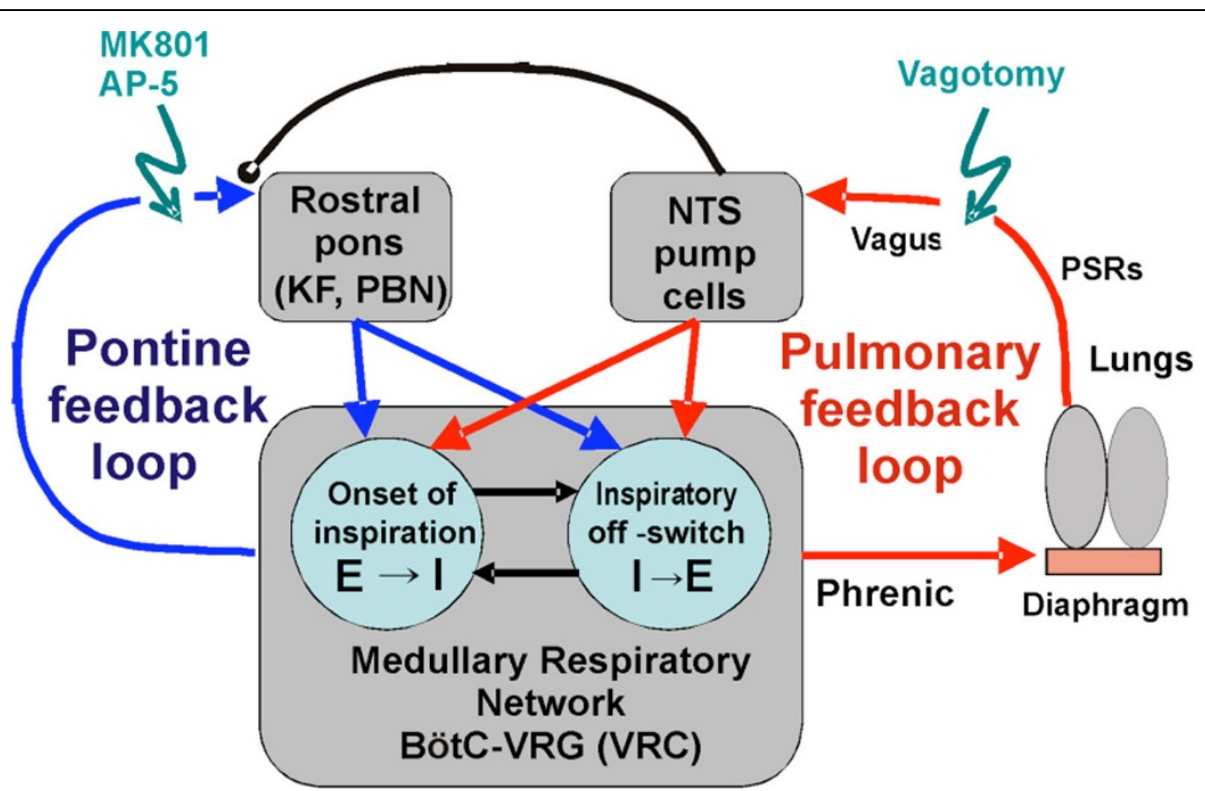

Figure 1 A general schematic diagram representing the system with two interacting feedback loops.

\footnotetext{
* Correspondence: ymolkov@iupui.edu

${ }^{1}$ Department of Mathematical Sciences, Indiana University - Purdue

University Indianapolis, IN 46202, USA

Full list of author information is available at the end of the article
} 
pattern and durations of inspiration $\left(T_{I}\right)$ and expiration $\left(T_{E}\right)$.

In our model: (a) the simulated vagotomy resulted in increases of both $T_{I}$ and $T_{E}$, (b) the suppression of pontine-medullary interactions led to the prolongation of $T_{I}$ at relatively constant, but variable $T_{E}$, and (c) these perturbations applied together resulted in "apneusis", characterized by a significantly prolonged $T_{I}$. The results of modeling were compared with, and provided a reasonable explanation for, multiple experimental data. The model was able to reproduce the experimentally demonstrated changes in $T_{I}$ and $T_{E}$ and phrenic pattern following vagotomy and/or pontine suppression by NMDA receptor blockers MK801and AP-5. According to the model these changes reflect the characteristic changes in the balance between the pontine and pulmonary feedback mechanisms involved in control of breathing during various cardio-respiratory disorders and diseases.

\section{Abbreviations}

AP-5 - amino-5-phosphonovaleric acid, NMDA receptor antagonist; BötC Bötzinger Complex; E - Expiratory or Expiration; I - Inspiratory or Inspiration; KF - Kölliker-Fuse nucleus; MK801 - dizocilpine maleate, NMDA receptor antagonist; NTS - Nucleus Tractus Solitarii; PBN - ParaBrachial Nucleus; PSRs Pulmonary Stretch Receptors; VRC - Ventral Respiratory Column; VRG Ventral Respiratory Group.

\section{Acknowledgements}

This study was supported by the National Institutes of Health: grants R33 HL087377, R33 HL087379, R01 NS057815, and R01 NS069220.

\section{Author details}

${ }^{1}$ Department of Mathematical Sciences, Indiana University - Purdue University Indianapolis, IN 46202, USA. ²Department of Neurobiology and Anatomy, Drexel University College of Medicine, Philadelphia, PA 19129.

USA. ${ }^{3}$ Departments of Medicine and Neurosciences, Case Western Reserve

University, Cleveland, $\mathrm{OH}$ 44106, USA.

Published: 8 July 2013

\section{Reference}

1. Smith JC, Abdala AP, Koizumi H, Rybak IA, Paton JF: Spatial and functional architecture of the mammalian brain stem respiratory network: a hierarchy of three oscillatory mechanisms. J Neurophysiol 2007, 98:3370-3387

doi:10.1186/1471-2202-14-S1-P338

Cite this article as: Molkov et al:: Control of breathing by interacting pontine and pulmonary feedback loops. BMC Neuroscience 2013 14(Suppl 1):P338.

\section{Submit your next manuscript to BioMed Central and take full advantage of:}

- Convenient online submission

- Thorough peer review

- No space constraints or color figure charges

- Immediate publication on acceptance

- Inclusion in PubMed, CAS, Scopus and Google Scholar

- Research which is freely available for redistribution

Submit your manuscript at www.biomedcentral.com/submit
C BioMed Central 